\title{
A convenient method for preparing rigid-core ionic liquid crystals
}

\author{
Julien Fouchet ${ }^{1}$, Laurent Douce ${ }^{*}$, Benoît Heinrich ${ }^{1}$, Richard Welter ${ }^{2}$ \\ and Alain Louati ${ }^{3}$
}

\section{Full Research Paper}

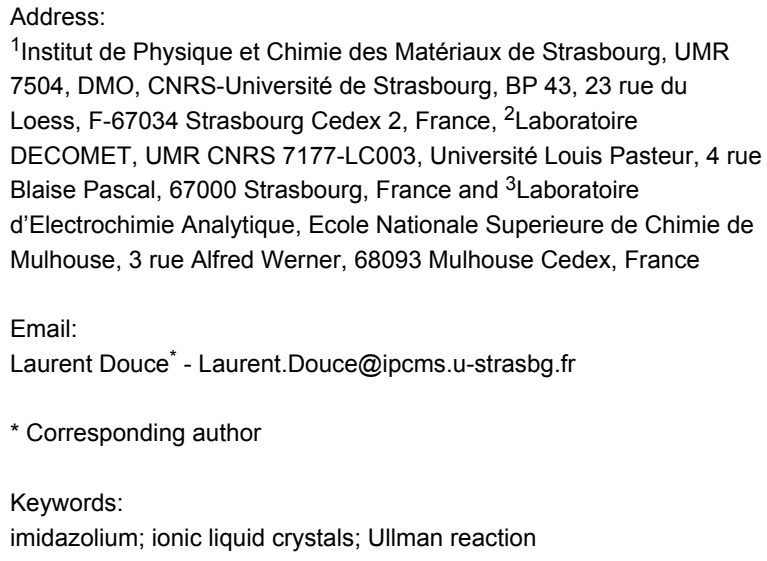

${ }^{1}$ Institut de Physique et Chimie des Matériaux de Strasbourg, UMR 7504, DMO, CNRS-Université de Strasbourg, BP 43, 23 rue du Loess, F-67034 Strasbourg Cedex 2, France, ${ }^{2}$ Laboratoire DECOMET, UMR CNRS 7177-LC003, Université Louis Pasteur, 4 rue Blaise Pascal, 67000 Strasbourg, France and ${ }^{3}$ Laboratoire d'Electrochimie Analytique, Ecole Nationale Superieure de Chimie de Mulhouse, 3 rue Alfred Werner, 68093 Mulhouse Cedex, France

Email:

Laurent Douce* - Laurent.Douce@ipcms.u-strasbg.fr

* Corresponding author

Keywords:

imidazolium; ionic liquid crystals; Ullman reaction

Beilstein Journal of Organic Chemistry 2009, 5, No. 51 doi:10.3762/bjoc.5.51

Received: 22 July 2009

Accepted: 29 September 2009

Published: 07 October 2009

Guest Editor: S. Laschat

(c) 2009 Fouchet et al; licensee Beilstein-Institut. License and terms: see end of document.

\begin{abstract}
An efficient, solvent free method for the N-arylation of imidazole by 1-(dodecyloxy)-4-iodobenzene using $\mathrm{Cu}$ (II)-NaY as catalyst and $\mathrm{K}_{2} \mathrm{CO}_{3}$ as base is reported. By this synthetic approach, mesomorphic 3-[4-(dodecyloxy)phenyl]-1-methyl-1H-imidazol-3-ium iodide was synthesized in a two-step procedure, and its mesomorphism has been fully investigated by polarised optical microscopy, differential scanning calorimetry and X-ray diffraction. In addition its lamellar crystal structure, electrochemical behaviour and UV (absorption and emission) properties are reported.
\end{abstract}

\section{Introduction}

Over the past decade extensive studies of ionic liquids (ILs) have revealed their many useful properties such as extremely low volatility, high thermal stability, non-flammability, high chemical and radiochemical stability, high ionic conductivity and wide electrochemical window [1-3]. In addition, the ILs have been used as reaction media increasing the yields of many syntheses and eliminating the hazards associated conventional solvents [4]. Thus are extremely versatile in that changes in both the cation and its counter anion can be used to finely tune their properties (for example: viscosity, melting point, polarity, hydrophilicity/hydrophobicity...). Important emerging applica- tions include those in separation and extraction processes, and in various electrochemical devices, such as lithium ion batteries, fuel cells, and capacitors, as well as in synthesis and catalysis [1-5].

Liquid crystals are characterised by both mobility and selforganisation at the macroscopic level [6]. Almost all such mesomorphic materials are based on molecules combining two antagonistic units consisting of rigid (aromatic) and flexible (alkyl) or hydrophilic (polar heads) and hydrophobic (alkyl chains) parts. The subtle balance of their effects governs the 
formation of a multitude of supramolecular architectures depending on the temperature (thermotropic liquid crystals) and/or of the solvent (lyotropic liquid crystals) [7,8]. In the case of the thermotropic liquid crystals the arrangements give rise to nematic phases (molecules are aligned along an orientational axis), smectic phases (orientational/positional order in the layers) and columnar phases (orientational/positional order in the columns). The lyotropic compounds display not only lamellar and columnar organization but also hierarchical selfassembly in spheres (micelles), ribbons and fibres. These unique properties lead to their applications ranging from display technology through templating media for synthesis to biological activity (targeting and transporting of drugs and gene materials) [9].

Full convergence of the ionic liquid and liquid crystal fields could provide a vast range of materials (Ionic liquid crystals, ILCs) with novel and tunable characteristics such as those of ordered and oriented hybrid compound semiconductors exhibiting both electronic and ionic conductivity [10]. For this, the imidazolium unit is an excellent platform that can be designed to promote liquid crystalline phases and easily be doped by a large diversity of anions [11-21]. Variation of the $\mathrm{N}$-substituents by Ullman coupling to extend the aromatic part is a facile means of creating this range [22,23].

Herein, we wish to report a solvent-free, N-arylation of imidazole as a means of expanding the aromatic core and obtaining unsymmetrical imidazolium liquid crystals (Scheme 1). We also describe the influence of the counter anion on the mesomorphism, electrochemistry and the UV properties of these imidazolium salts.

$$
\mathrm{A}^{\ominus}=\mathrm{I}^{-}(\mathbf{1 a}), \mathrm{BF}_{4}^{-} \text {(1b), } \mathrm{PF}_{6}^{-} \text {(1c), } \mathrm{CF}_{3} \mathrm{SO}_{3}^{-} \text {(1d) }
$$

Scheme 1: 1-[4-(dodecyloxy)phenyl]-3-methyl-1H-imidazol-3-ium mesogenic salts.

\section{Results and Discussion Synthesis and characterization}

Compound 1a was obtained in a two-step procedure. The first step was a coupling reaction between 1-(dodecyloxy)-4iodobenzene and imidazole using $\mathrm{Cu}(\mathrm{II})-\mathrm{NaY}$ as catalyst in the presence of potassium carbonate as base [23]. The reaction took place without solvent at $180{ }^{\circ} \mathrm{C}$ in a sealed tube over $72 \mathrm{~h}$ to afford 1-[4-(dodecyloxy)phenyl]-1H-imidazole (A) in a good
$(<80 \%)$ and reproducible yield (Scheme 2$)$. Swager has already published the synthesis of compound $\mathbf{A}$ under standard Ullman conditions $\left(\mathrm{K}_{2} \mathrm{CO}_{3}, \mathrm{CuI}\right.$, L-proline in DMSO, $16 \mathrm{~h}$ at $\left.110{ }^{\circ} \mathrm{C}\right)$ [22].

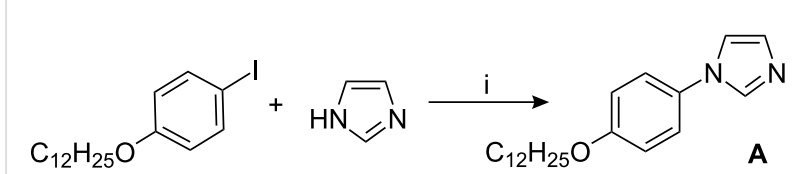

Scheme 2: Synthesis of the imidazole A. Reaction conditions: (i) aryl iodide $(1.37 \mathrm{mmol})$, imidazole $(1.69 \mathrm{mmol}), \mathrm{K}_{2} \mathrm{CO}_{3}(1.51 \mathrm{mmol})$, $\mathrm{Cu}(\mathrm{II}) \mathrm{NaY}(148 \mathrm{mg}), 72 \mathrm{~h}$ at $180^{\circ} \mathrm{C}$ in a sealed tube.

The aryl-imidazole A was purified by column chromatography (ethyl acetate as eluent) on silica and characterized spectroscopically. The second step involved alkylation of $\mathbf{A}$ by iodomethane to give salt 1 a in $89 \%$ yield after purification (Scheme 3). Distinctive signals for the $\mathrm{CH}$ ( $1 H$-imidazolium) group appear in the ${ }^{1} \mathrm{H}$ and ${ }^{13} \mathrm{C}$ NMR spectra at $10.45 \mathrm{ppm}$ and 134.97 ppm respectively.

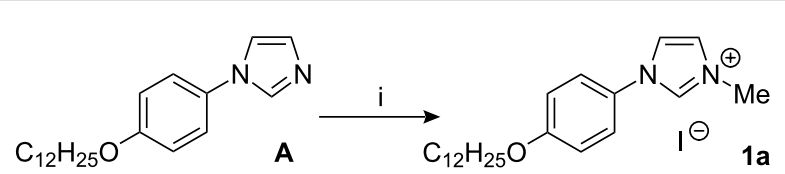

Scheme 3: Synthesis of methyl imidazolium 1a. Reaction conditions: (i) Mel in sealed tube, $54 \mathrm{~h}$ at RT.

Single crystals of 1a suitable for X-ray diffraction were obtained by slow diffusion of ether into a $\mathrm{CH}_{2} \mathrm{Cl}_{2}$ solution. The compound 1a crystallizes in the triclinic space group $P 1$. A partly labelled ORTEP view showing non-classical hydrogen bonds and C-H.. $\pi$ interactions is given in Figure 1 (the interactions also being listed in Table 1). The alkyloxy chains are quite parallel, as is clear from the crystal packing given in Figure 2, with segregation between the rigid part (including iodine atoms) and the alkyloxy chains ( $\approx 20 \AA$, see Figure 2$)$. The length of the molecule in the crystalline state is about $24 \AA$.

It should be emphasised that the lattice area $(A=a \cdot b \cdot \sin (\gamma)=$ $\left.2 \mathrm{~V} / \mathrm{d}_{001}=57.1 \AA^{2}\right)$ is about three times the transverse area of an all-trans crystallised chain and that even so the alkyl tails organise in segregated double layers, without interdigitation but with a tilt angle of $71^{\circ}$ with respect to the layer normal. This large tilt angle just compensates the discrepancy between areas, maintaining the compactness of the packing and the flatness of the segregated ionic and aliphatic double layers. Apart from the crystallised state of the tails, this structure is very close to a smectic type of organisation. The segregation between the alkyl 


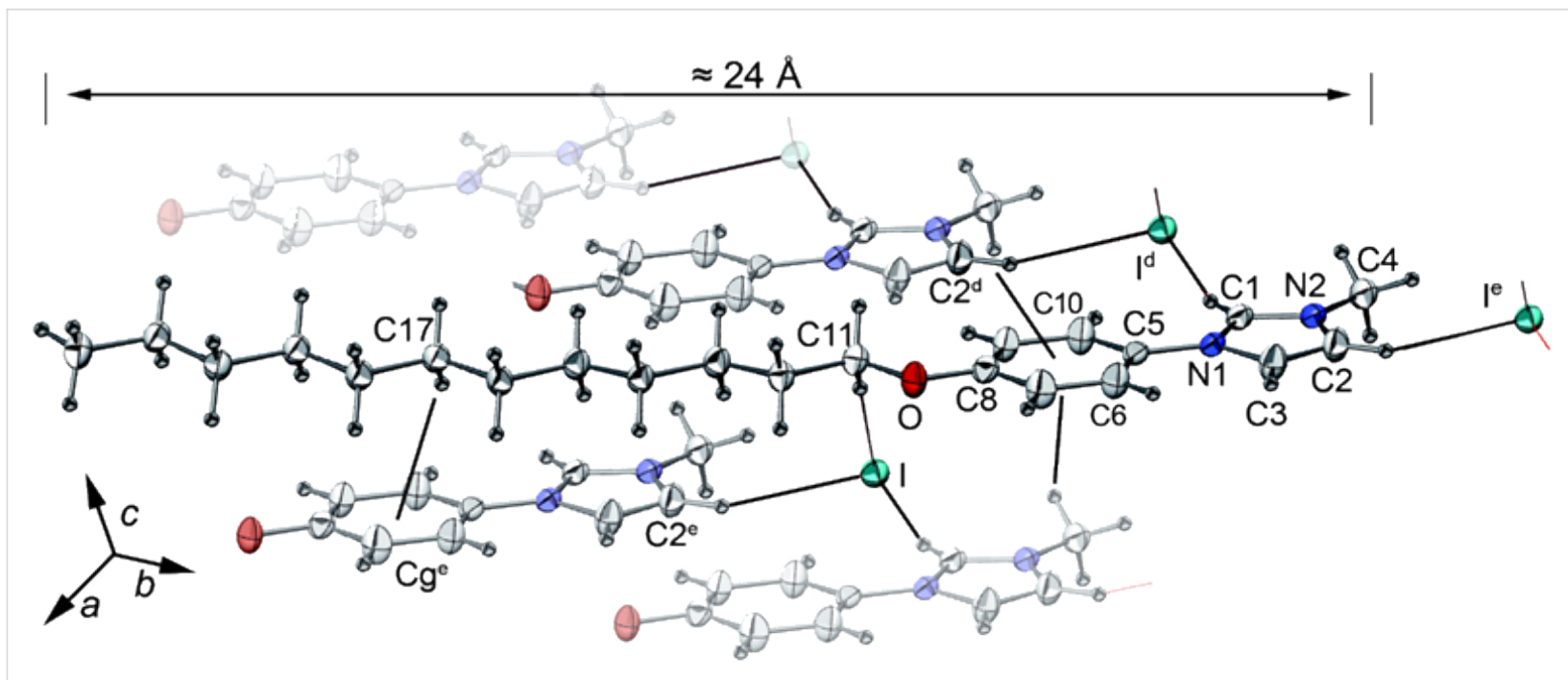

Figure 1: ORTEP view of compound 1a with partial labelling. The closest molecules are represented (with lower opacity) when connected by $\mathrm{CH}-\pi$ and/or non classical $\mathrm{H}$-bonds (black thin lines). The ellipsoids enclose $50 \%$ of the electronic density. Symmetry operators for equivalent positions: $\mathrm{d}= \pm 1+x, y, z ;{ }^{e}=1+x, 1+y, z$.

Table 1: Non-classical hydrogen bonds and $\mathrm{CH}$.. $\pi$ interactions ${ }^{\mathrm{a}}$ occurring in $\mathbf{1 a}$. $\mathbf{C g}$ is the phenyl ring (C5 to $\left.\mathrm{C} 10\right)$. Symmetry operators for equivalent positions: ${ }^{d}= \pm 1+x, y, z ;{ }^{e}=1+x, 1+y, z$.

\begin{tabular}{|c|c|c|c|c|}
\hline C-H..I & $\mathrm{d}_{\mathrm{C}-\mathrm{H}}(\AA)$ & $\mathrm{d}_{\mathrm{H}-\mathrm{I}}(\AA)$ & $\mathrm{d}_{\mathrm{C}-\mathrm{I}}(\AA)$ & $\mathrm{C}-\mathrm{H}-\mathrm{I}\left({ }^{\circ}\right)$ \\
\hline $\mathrm{C} 1-\mathrm{H} 1 . . \mathrm{I}^{\mathrm{d}}$ & 0.95 & 2.8270 & $3.746(5)$ & 163.1 \\
\hline $\mathrm{C} 2-\mathrm{H} 2 . \mathrm{I}^{\mathrm{e}}$ & 0.95 & 2.9123 & $3.822(5)$ & 160.6 \\
\hline C11-H11B..I & 0.95 & 3.0026 & $3.992(5)$ & 179.2 \\
\hline C-H..Cg & $\mathrm{d}_{\mathrm{C}-\mathrm{H}}(\AA)$ & $\mathrm{d}_{\mathrm{H}-\mathrm{Cg}}(\AA)$ & $\mathrm{d}_{\mathrm{C}-\mathrm{I}}(\AA)$ & $\mathrm{C}-\mathrm{H}-\mathrm{Cg}\left({ }^{\circ}\right)$ \\
\hline C4-H4A...Cg ${ }^{d}$ & 0.95 & 3.109 & 3.502 & 105.6 \\
\hline C4-H4B...Cg ${ }^{d}$ & 0.95 & 3.309 & 3.502 & 93.1 \\
\hline C17-H17B..Cg ${ }^{\mathrm{e}}$ & 0.95 & 3.310 & 4.207 & 151.5 \\
\hline
\end{tabular}

aplaton software [24].

tails and the charged rigid parts indicates that by melting the chains they could show liquid crystal behaviour at a higher temperature. In order to understand the influence of the anion on the electrochemical, UV properties and mesomorphism, we prepared compounds with $\mathrm{BF}_{4}^{-}(\mathbf{1 b}), \mathrm{PF}_{6}^{-}(\mathbf{1 c}), \mathrm{CF}_{3} \mathrm{SO}_{3}^{-}$(1d) and $\left(\mathrm{CF}_{3} \mathrm{SO}_{2}\right)_{2} \mathrm{~N}^{-}(\mathbf{1 e})$ anions in excellent yield by anion metathesis in water/ $\mathrm{CH}_{2} \mathrm{Cl}_{2}$ as solvent (Scheme 4).

All these compounds were fully characterized by ${ }^{1} \mathrm{H}$ NMR, ${ }^{13} \mathrm{C}$ NMR $\left\{{ }^{1} \mathrm{H}\right\}$, FT-IR and UV spectroscopy, as well as elemental analysis. The IR spectra showed typical anion vibrations at $1024 \mathrm{~cm}^{-1}\left(\mathbf{1 b ~ B F}{ }_{4}^{-}\right), 826 \mathrm{~cm}^{-1}\left(\mathbf{1} \mathrm{cF}_{6}{ }^{-}\right), 1269$ and $1028 \mathrm{~cm}^{-1}\left(\mathbf{1} \mathrm{d} \mathrm{CF}_{3} \mathrm{SO}_{3}{ }^{-}\right), 1358$ and $1183 \mathrm{~cm}^{-1}(\mathbf{1 e}$ $\left.\left(\mathrm{CF}_{3} \mathrm{SO}_{2}\right)_{2} \mathrm{~N}^{-}\right) .{ }^{1} \mathrm{H} \mathrm{NMR}$ spectra were recorded in $\mathrm{CDCl}_{3}$, in which the chemical shift for the $\mathrm{CH}(1 H$-imidazolium $)$ is very dependent upon the anion, with $\delta 10.45$ (1a) 9.37 (1b), 9.10 (1c), 9.41 (1d) and 8.98 ppm (1e). This dependency is certainly due to the interactions though H-bonding and the charge localisation on the anion. The UV spectra displays typical charge transfer $\left(\pi-\pi^{*}\right.$ or $\left.\mathrm{n}-\mathrm{n}^{*}\right)$ transitions in $\mathrm{CH}_{2} \mathrm{Cl}_{2}$ at $240 \mathrm{~nm}(\mathbf{1 a} \varepsilon=$ $\left.24000 \mathrm{M}^{-1} \mathrm{~cm}^{-1}\right), 255 \mathrm{~nm}\left(\mathbf{1 b} \varepsilon=10500 \mathrm{M}^{-1} \mathrm{~cm}^{-1}\right), 249 \mathrm{~nm}$ $\left(\mathbf{1 c} \varepsilon=11700 \mathrm{M}^{-1} \mathrm{~cm}^{-1}\right), 256 \mathrm{~nm}\left(\mathbf{1 d} \varepsilon=10100 \mathrm{M}^{-1} \mathrm{~cm}^{-1}\right)$ and $255 \mathrm{~nm}\left(1 \mathrm{e} \varepsilon=11100 \mathrm{M}^{-1} \mathrm{~cm}^{-1}\right)$. A blue emission was also observed at $384 \mathrm{~nm}$ (Figure 3).

\section{Investigation of the Liquid Crystalline Beha- viour}

The thermogravimetric analysis of compounds $\mathbf{1 a}-\mathbf{e}$ showed the general stability order to be $\mathrm{I}^{-}<\mathrm{BF}_{4}{ }^{-} \approx \mathrm{PF}_{6}{ }^{-}<\mathrm{CF}_{3} \mathrm{SO}_{3}{ }^{-}<$ $\left(\mathrm{CF}_{3} \mathrm{SO}_{2}\right)_{2} \mathrm{~N}^{-}$(Figure 4). 


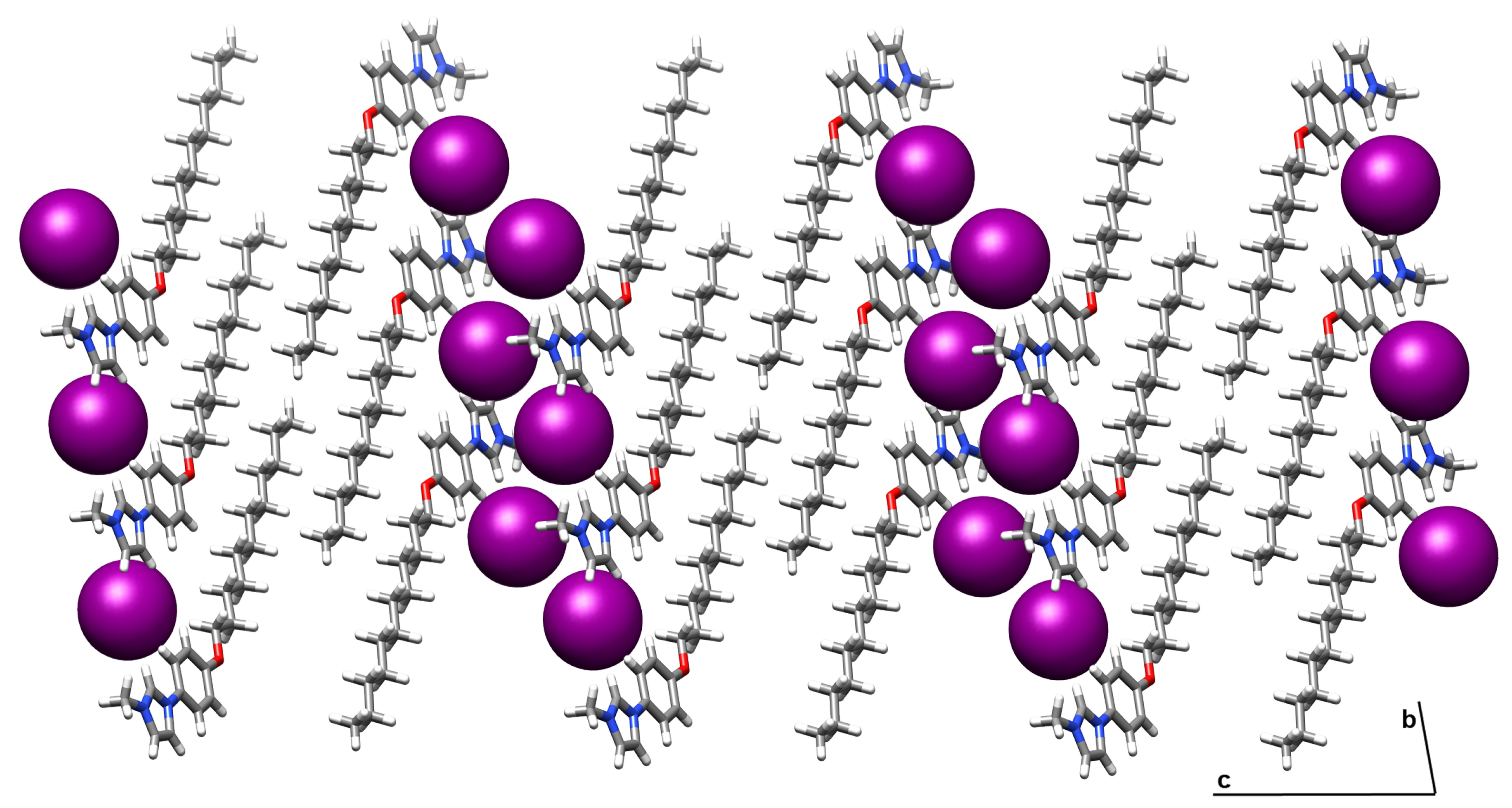

Figure 2: Packing diagram of compound $1 \mathrm{a}$ in projection in the $(b, c)$ lattice plane. Large spheres represent the iodine atoms.

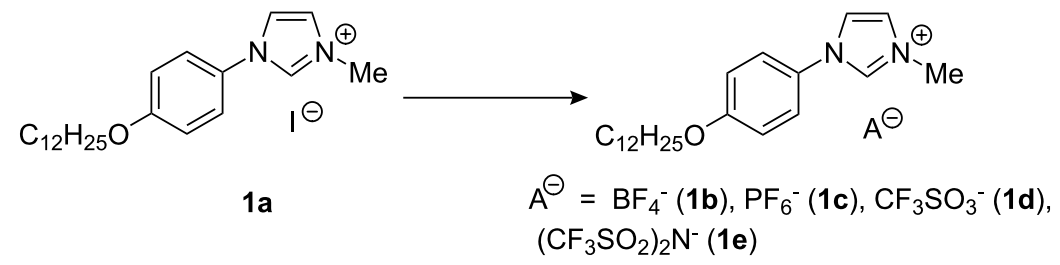

Scheme 4: Anion metathesis in water/ $\mathrm{CH}_{2} \mathrm{Cl}_{2}$ as solvent.

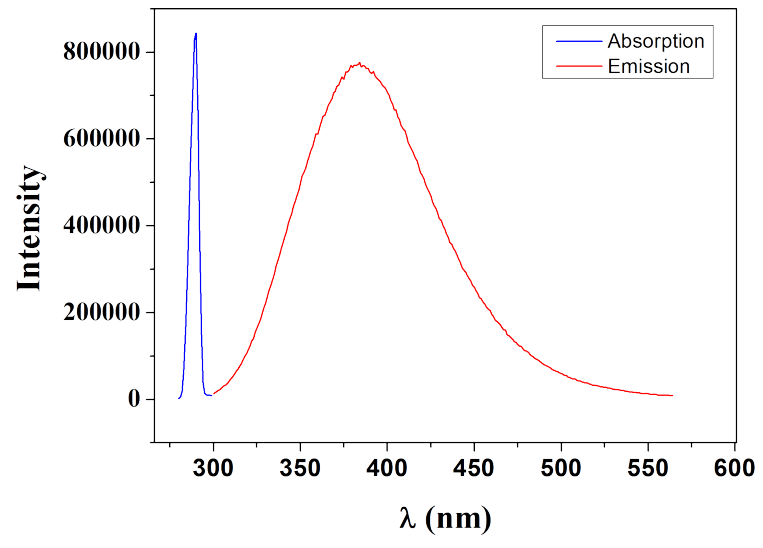

Figure 3: Spectra of absorption (red line) and emission (blue line) of 1 a.

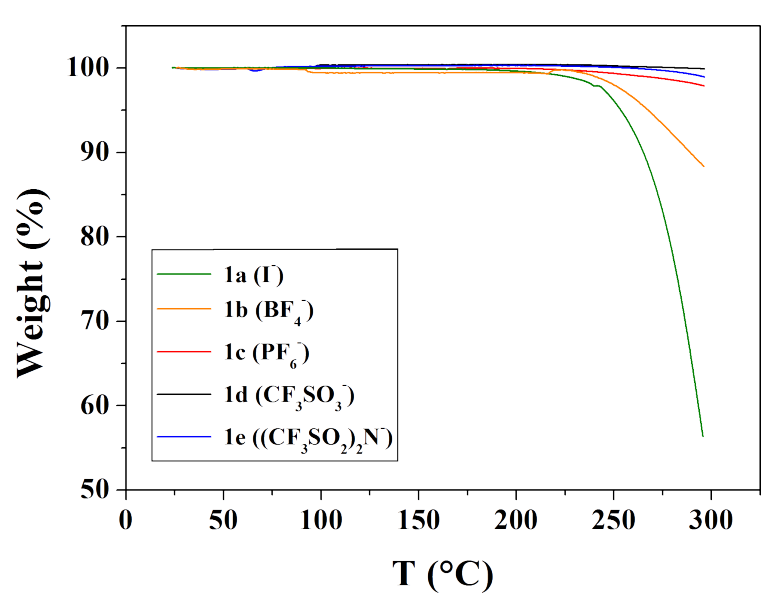

Figure 4: TGA measurements of the compounds 1a-e (rate $10^{\circ} \mathrm{C} \cdot \mathrm{min}^{-1}$, in air). 
Table 2: Phase transition temperatures and corresponding enthalpies determined from the $2^{\text {nd }}$ heating and cooling.

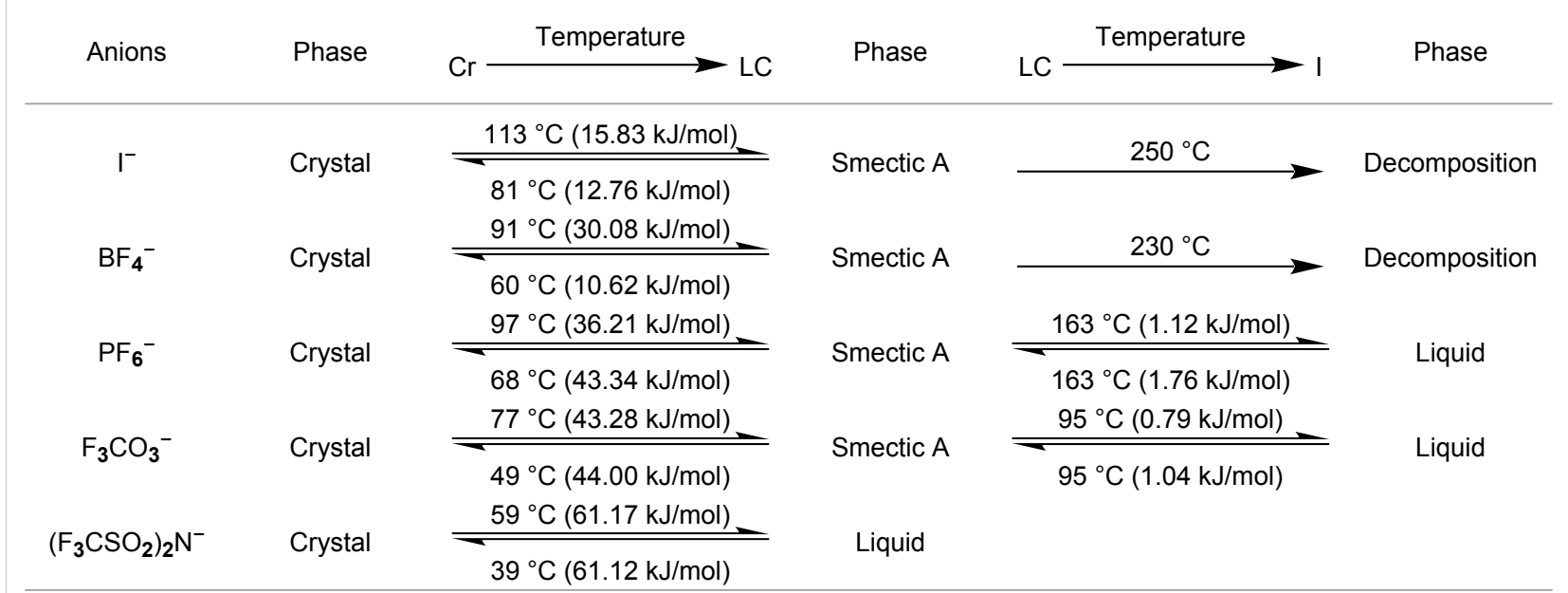

Legend: Cr: Crystal, LC: Liquid Crystal, I: Isotropic Liquid.

For all the compounds, the mesomorphic behaviour and phase transition temperatures were investigated by polarized optical microscopy (POM), differential scanning calorimetry (DSC), and powder X-ray diffractometry (XRD). To avoid possible effects of hydration of the materials, all were dried in vacuo before X-ray and DSC analyses. The phase transition temperatures and the corresponding enthalpy changes derived for compounds 1a-e are compiled in Table 2, while typical results are displayed in Figure 5.

The high stability of the compounds was also demonstrated by the absence of significant perturbation of the DSC patterns following several heating-cooling cycles. Compounds $\mathbf{1 e}$, not unexpectedly, do not show thermotropic behaviour, while the data for 1a-d give an order of anion stabilisation of liquid crystal behaviour of $\mathrm{Br}^{-}>\mathrm{BF}_{4}{ }^{-}>\mathrm{PF}_{6}{ }^{-}>\mathrm{CF}_{3} \mathrm{SO}_{3}{ }^{-}$(see Figure 5).

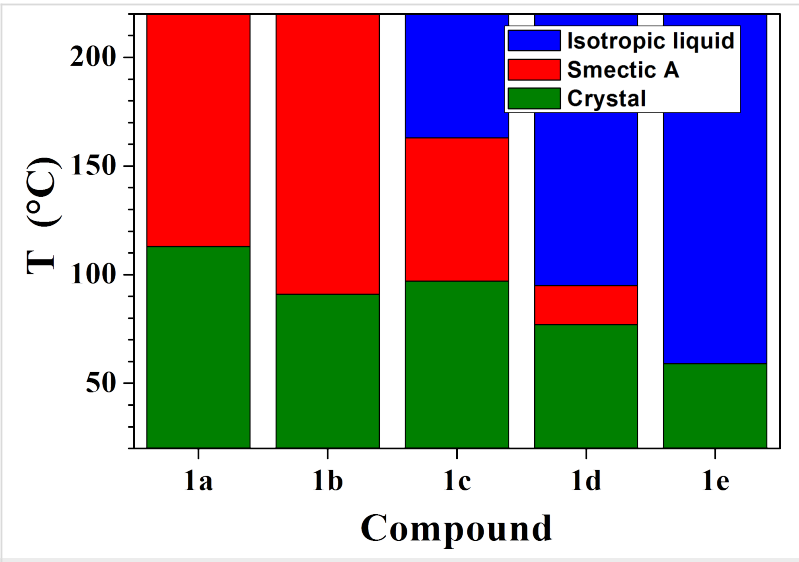

Figure 5: Phase transition temperatures of compounds 1a-e.
The optical textures observed during slow cooling from isotropic melt showed the emergence of a smectic A phase (appearance of Batônnet rods, turning into a wide, fan-like, focal-conic texture). The smectic structure of the liquid crystal phase was confirmed by XRD. The X-ray pattern (Figure 6) of the Smectic A form recorded at $120^{\circ} \mathrm{C}$ contains a diffuse band at $4.6 \AA$ (wide angle), which shows clearly that the alkyl chains have a liquid-like structure and are segregated from the aromatic cores.

The layer thickness in the Smectic A phase was determined from the position of the sharp reflection in the small angle region $\left(\mathrm{d}=39.8 \AA\right.$ at $\left.120{ }^{\circ} \mathrm{C}\right)$ and corresponds to the alternation between the sublayer formed by the molten chains and the sublayer formed by the ionic double layer and the mesogenic

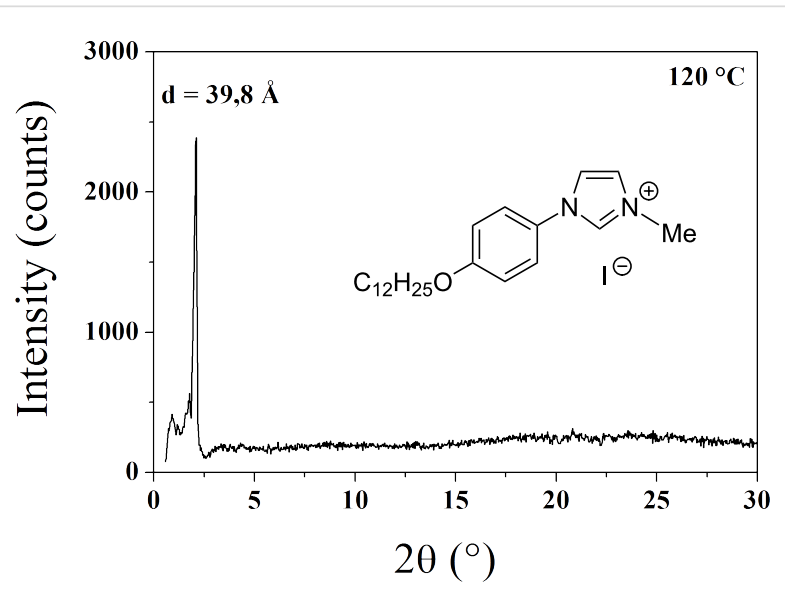

Figure 6: Powder X-ray diffraction pattern of compound $1 \mathrm{a}$ in the liquid crystal state $\left(T=120^{\circ} \mathrm{C}\right)$. 
parts. The thickness of the corresponding sublayers' alternation in the crystalline phase is given by the location of the $\mathrm{d}_{001}$ reflection $\left(\mathrm{d}_{001}=20.21 \AA\right.$ from single crystal pattern at room temperature). Despite the enormous difference in layer thicknesses between both phases (the extrapolation of the variation versus temperature gives $\mathrm{d}=46.5 \AA$ at $20{ }^{\circ} \mathrm{C}$ i.e. more than twice $\mathrm{d}_{001}$ ), the difference in molecular volume (smectic phase: $\mathrm{V}_{\text {mol }}=622 \AA^{3}$ at $20{ }^{\circ} \mathrm{C}$; crystalline phase: $\mathrm{V}_{\mathrm{mol}}=\mathrm{V} / 2=$ $577 \AA^{3}$ ) just coincides with the contribution of the chain melting $[25,26]$, indicating that the partial volume of the ionic sublayer does not change significantly between both phases. The observed layer thickness change is therefore the consequence of the different "molecular areas" S, i.e. the projection area of a mesogen counter-ion assembly within the mean smectic plane $\left(\mathrm{S}=2 \mathrm{~V}_{\mathrm{mol}} / \mathrm{d}\right)$, which is identical to the lattice area in the crystalline phase $\left(\mathrm{S}=\mathrm{V} / \mathrm{d}_{001}\right)$. Thus, since no significant volume change is involved in the shrinking of $S$ from $57.1 \AA^{2}$ in the crystalline phase to $27 \AA^{2}$ in the smectic A phase (value at $20^{\circ} \mathrm{C}$ obtained from the extrapolation of the variation of $\mathrm{S}$ versus temperature), the ionic sublayer thickness $\mathrm{d}_{\mathrm{c}}$ (determined as $\mathrm{dc}=2\left[\mathrm{~V}_{\mathrm{mol}} /-\mathrm{V}_{\mathrm{ch}}\right] / \mathrm{S}, \mathrm{V}_{\mathrm{ch}}$ being the chain volume) simultaneously expands in proportion (from $9.5 \AA$ in the crystalline phase to $20 \AA$ in the smectic phase at $20{ }^{\circ} \mathrm{C}$ ). These lateral shrinkage and longitudinal extension events are the result of a ruffling process of the ionic sublayers, starting from the completely flat state in the crystalline phase shown by the single crystal structure (see Figure 7).

The maximum degree of ruffling in the smectic A phase is reached just before crystallisation, since the experimental temperature dependence of $\mathrm{S}$ and $\mathrm{d}_{\mathrm{c}}$ indicates that the sublayers continuously spread with increasing temperature (see Figure 8).

The counter-ion substitution within the series 1 involves large changes of $\mathrm{S}$, but the temperature dependence and dc values are roughly the same for all terms (see Figure 9).

The influence of the substitution can therefore be considered as an anion size effect, since the lattice area expands with increasing counter-ion bulkiness without change of the degree of ruffling (the small discrepancies for compound 1d $\left(\mathrm{CF}_{3} \mathrm{SO}_{3}{ }^{-}\right)$being explained by the presence of the $\mathrm{CF}_{3}$ lateral group, which contributes to $d_{c}$ and perturbates slightly the interface with the aliphatic sublayer). It should be emphasised that the stability of the smectic A phase is not determined by the degree of ruffling of the ionic sublayer but by the folding degree of the tails and therefore the thickness of the aliphatic sublayers. Thus, depending upon the anion size, the isotropisation occurs at various temperatures, but for approximately the same maximum molecular area $\left(\mathrm{S}^{\max } \approx 41 \AA^{2}\right)$ and therefore similar minimum aliphatic sublayer thicknesses $\left(\mathrm{d}_{\mathrm{ch}}{ }^{\min } \approx 19 \AA\right)$.

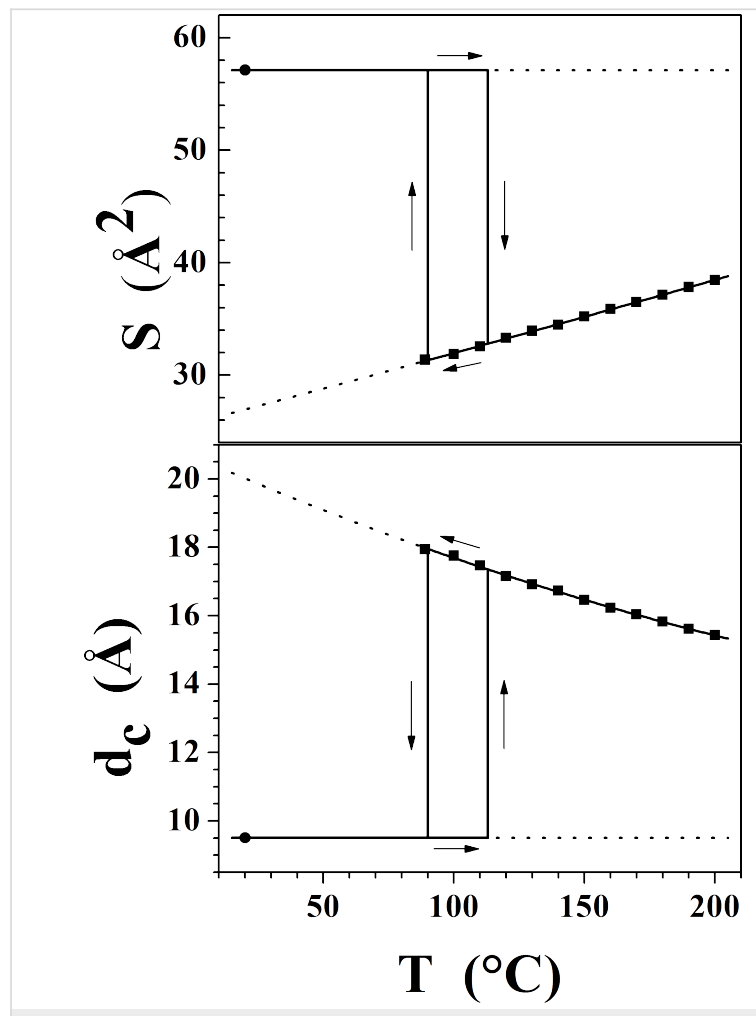

Figure 8: Comparison of the molecular area $S$ and of the ionic sublayer thickness $\mathrm{d}_{\mathrm{c}}$ (including mesogenic segments) in the crystalline phase (circle) and in the smectic A phase (squares) for compound 1a $\left(I^{-}\right)$.

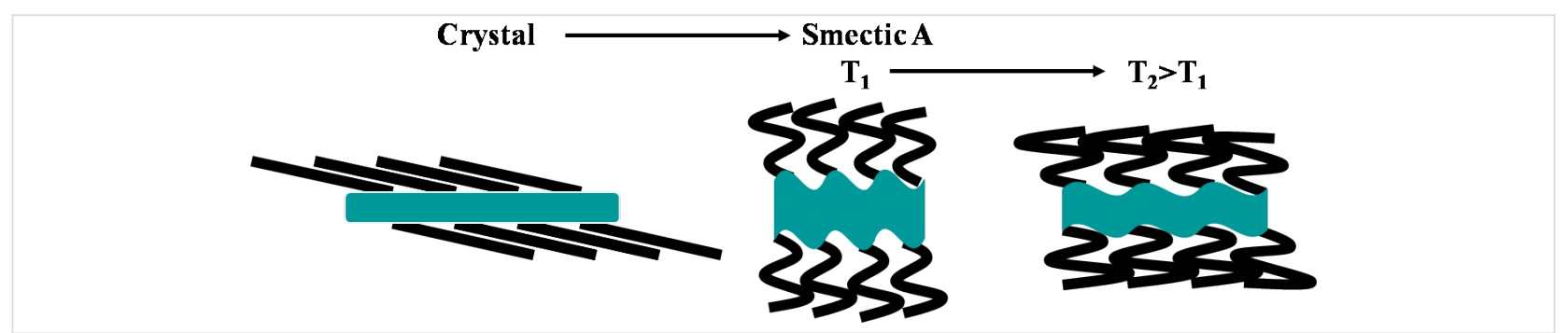

Figure 7: The melting process involves the ruffling of the ionic sublayer. In the smectic phase, the ruffling degree decreases with increasing temperature. 


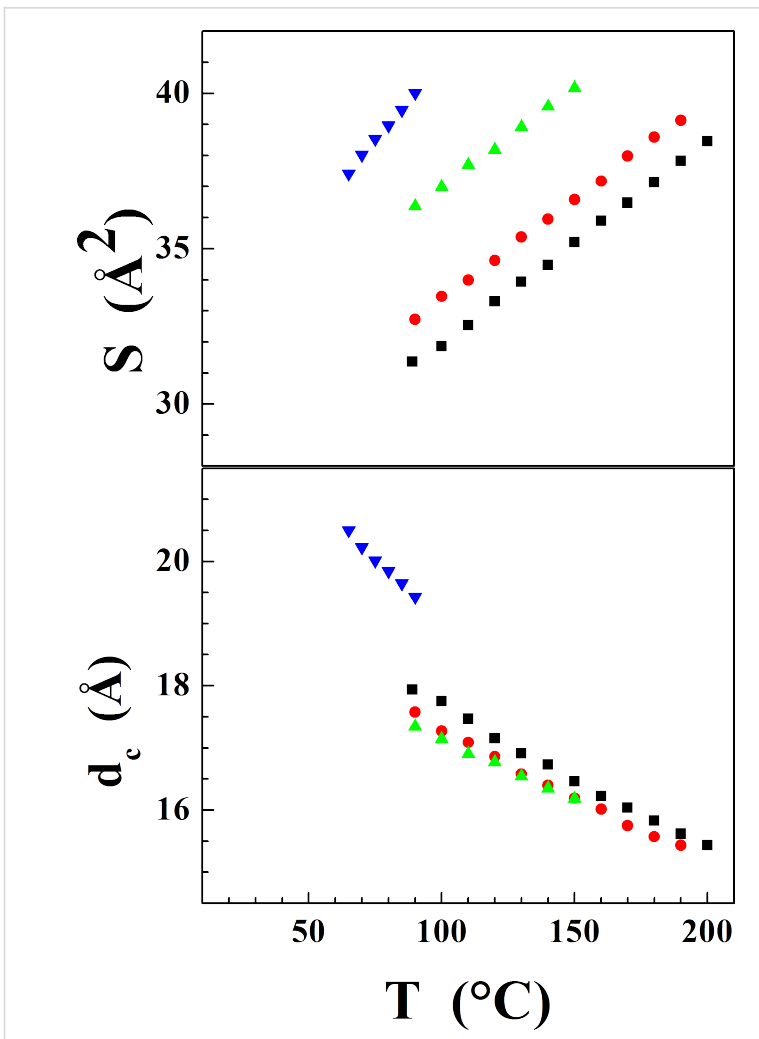

Figure 9: Variation with the counter-ion of the molecular area $S$ and of the ionic sublayer thickness $d_{c}$ (including mesogenic segments) in the smectic $A$ phase for series 1: squares: $1 \mathbf{a}\left(\mathrm{I}^{-}\right)$; circles: $\mathbf{1 b}\left(\mathrm{BF}_{4}^{-}\right)$; up triangles: 1c $\left(\mathrm{PF}_{6}{ }^{-}\right)$; down triangles: $1 \mathbf{d}\left(\mathrm{CF}_{3} \mathrm{SO}_{3}{ }^{-}\right)$.

To summarise, the large discrepancy between the lattice area and the cross section of the aliphatic chains are taken into account differently in the crystalline and in the smectic molecular organisations. In the crystalline phase, the ionic sublayers just impose their area and the tails tilt until dense packing is reached. In the smectic phase, tail tilting is not favourable upon the amphipathic expelling at the interface with the ionic sublayer and the system adopts a compromise molecular area associating ruffled ionic sublayers and folded aliphatic tails. With increasing temperature, the aliphatic chains spread more easily and the organisation shifts toward flat sublayers. A more detailed investigation of the molecular area variation in series involving both, counter-ion substitution and tail-length variation, has been presented elsewhere for a very similar cationic structure $[20,25,26]$.

\section{Electrochemical behaviour}

Cyclic voltammetry was used to determine the electrochemical behaviour of the compounds $\mathbf{1 a}, \mathbf{1 b}$ and $\mathbf{1 c}$, the voltammograms being recorded in $\mathrm{CH}_{3} \mathrm{CN}$ solutions containing $0.1 \mathrm{M}$ $\mathrm{NBu}_{4} \mathrm{PF}_{6}$ as supporting electrolyte at a platinum working electrode. The peak potentials are given vs. a SCE. Representative cyclic voltammograms of $\mathbf{1 a}$ are shown in Figure 10. The anodic portion of the voltage scan displays two oxidation steps having peak potentials of $0.42 \mathrm{~V}$ and $0.68 \mathrm{~V}$, and likely involve the formation of $I_{2}$ and possibly then a higher-oxidation-state iodine $\left(\mathrm{I}_{3}{ }^{-}\right)$species. As seen for $\mathbf{1 a}$ (Figure 9), for $\mathbf{1 b}$ and $\mathbf{1 c}$ the cathodic portion of the voltage scan displays only an irreversible reduction step at ca $1.58 \mathrm{~V}$, which corresponds to the reduction of the cationic imidazolium species. Note that the peak at $-0.8 \mathrm{~V}$ is probably due to the reduction of $\mathrm{O}_{2}$ which is difficult to eliminate from the solution.

\section{Conclusion}

In conclusion, we report synthetic methodology based on Ullman coupling to extend the imidazolium aromatic core. From this coupling product we have synthesized and fully characterized new mesomorphic compounds with different anions.
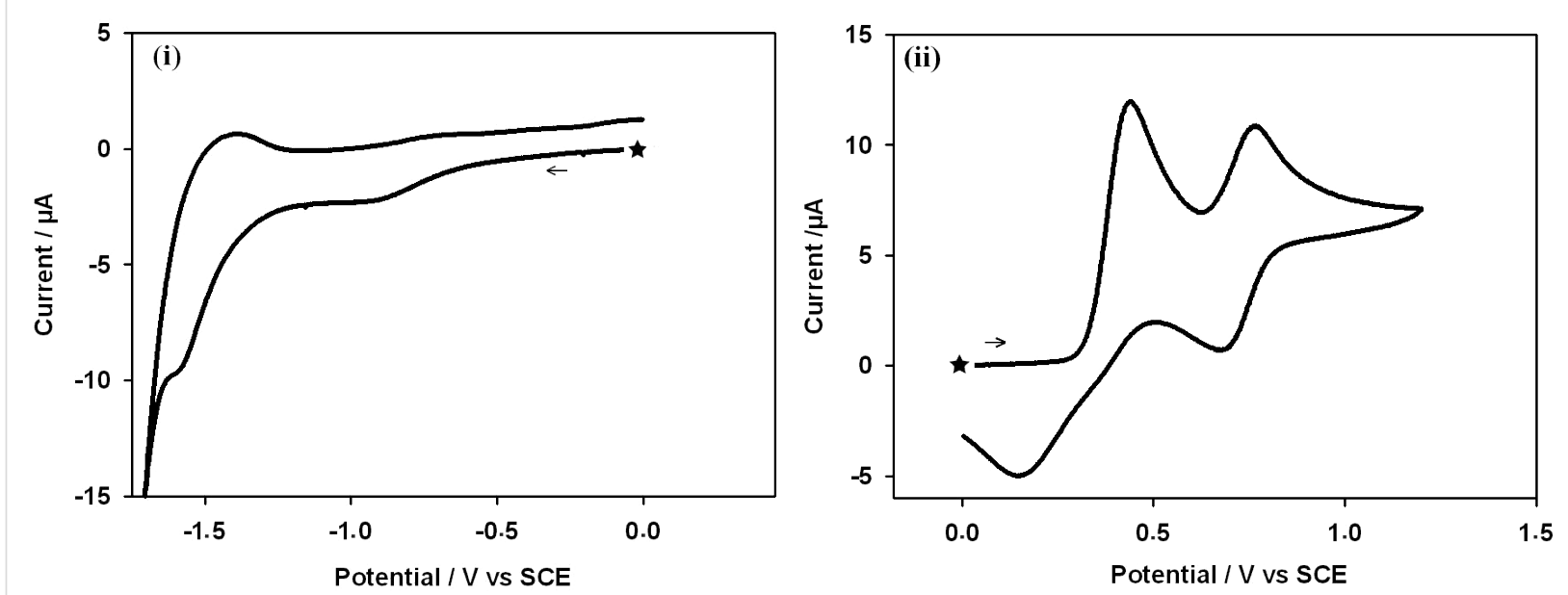

Figure 10: Cyclic voltammogram of $1 \mathrm{a}$ in $\mathrm{CH}_{3} \mathrm{CN}\left(0.1 \mathrm{M} \mathrm{NBu}_{4} \mathrm{PF}_{6}\right)$ : (i), (ii) cathodic and anodic range of the voltage scan. Scan rate $100 \mathrm{mV} \cdot \mathrm{s}^{-1}$. The black star denotes the initial and final potential. 
We have also determined a structure by X-ray diffraction on a single crystal. The crystallisation shows the completely lamellar segregation between the flexible chains and the rigid part. The layers are linked to each other by the semi-interdigitation of alkyl tails. Despite an enormous difference between the crosssection of crystallised chains and the lattice area imposed by the organisation within the ionic sublayers, the latter just remain flat and the tails undergo a double layer dense packing with $71^{\circ}$ tilting with respect to the layer normal. In the smectic phase, area matching is achieved by ruffling of the sublayers and folding of the molten aliphatic tails, the degree of ruffling decreasing with increasing temperature. The electrochemical windows have been measured and we are attempting to measure the carrier mobility in order to fully assess the prospects for using these molecules in molecular electronics. We intend also to introduce different length tails in order to obtain room temperature ionic liquid crystals, aswell as to explore use of the coupling reaction between imidazole and other aromatics and heterocycles to tune the electronic properties.

\section{Experimental}

X-ray diffraction pattern of powder samples in Lindeman capillaries or sealed cells were measured in transmission by using a focused $\mathrm{CuK}_{\alpha 1}$ linear beam, temperature control being within $0.03{ }^{\circ} \mathrm{C}$ and acquisition being conducted with an Inel CS120 curved counter. The molecular volumes of all compounds were calculated with an accuracy of $0.5 \%$ from the measurements performed for an analogous compound [26] and from the methylene and counter ion partial volumes.

All reagents were purchased from commercial suppliers and used without further purification. Chromatography was carried out with Merck silica gel 60 (40-63 mm). Analytical TLC was performed with Merck silica gel 60 F254 aluminium sheets. ${ }^{1} \mathrm{H}$ $\mathrm{NMR}$ and ${ }^{13} \mathrm{C}$ NMR (300 $\mathrm{MHz}$ and $75 \mathrm{MHz}$ respectively) spectra were recorded with a Bruker Avance 300 spectrometer at $25^{\circ} \mathrm{C}$. Chemical shifts, $\delta$, are reported in ppm using TMS as internal standard, spin-spin coupling constants, $J$, are given in $\mathrm{Hz}$ and the abbreviations s, br, s, t, q, m were used to denote respectively the multiplicity of signals: singlet, broad singlet, triplet, quadruplet, multiplet. Infrared spectra were recorded (KBr pastille) with a spectrophotometer IR Digital FTS 3000 $\mathrm{UV} / \mathrm{Vis}$ spectra were recorded with a spectrophotometer U-3000. Elemental analyses were performed by the analytical service at the Institut Charles Sadron and by the analytical service at the Université de Strasbourg (Strasbourg, France) The optical structures of mesophases were studied with a Leitz polarizing microscope equipped with a Mettler FP80 hot stage and an FP80 central processor. The TGA measurements were carried out on a SDTQ 600 apparatus at scanning rate of $10^{\circ} \mathrm{C} \cdot \mathrm{min}^{-1}$. The transition temperatures and enthalpies were measured by differential scanning calorimetry with a DSC Q1000 from TA Instruments at different temperature rates $\left(5^{\circ} \mathrm{C} \cdot \mathrm{min}^{-1}, 2^{\circ} \mathrm{C} \cdot \mathrm{min}^{-1}\right)$ on heating and cooling.

\section{1-[4-(Dodecyloxy)phenyl]-1H-imidazole (A)}

1-Dodecyloxy-4-iodobenzene (0.533 g, $1.37 \mathrm{mmol})$, imidazole $(0.115 \mathrm{~g}, 1.69 \mathrm{mmol}), \mathrm{K}_{2} \mathrm{CO}_{3}(0.288 \mathrm{~g}, 1.51 \mathrm{mmol})$ and $\mathrm{Cu}(\mathrm{II})-\mathrm{NaY}(0.148 \mathrm{~g})$ were heated in sealed tube to $180{ }^{\circ} \mathrm{C}$ for $72 \mathrm{~h}$. The reaction mixture was filtered to remove the catalyst and the filtrate was purified by column chromatography (silica gel, ethyl acetate) to afford pure A $(0.378 \mathrm{~g}, 84 \%)$.

${ }^{1} \mathrm{H}$ NMR (300 MHz, $\left.\mathrm{CDCl}_{3}\right): \delta=0.88\left(\mathrm{t}, 3 \mathrm{H}, J=6.5 \mathrm{~Hz}, \mathrm{CH}_{3}\right.$ aliphatic chain), 1.27 (broad s, $16 \mathrm{H}, \mathrm{CH}_{2}$ aliphatic chain), 1.42-1.49 (m, 2H, O-CH $\left.-\mathrm{CH}_{2}-\mathrm{CH}_{2}\right), 1.75-1.84(\mathrm{~m}, 2 \mathrm{H}$, $\left.\mathrm{O}-\mathrm{CH}_{2}-\mathrm{CH}_{2}\right), 3.98$ (t, $\left.2 \mathrm{H}, J=6.6 \mathrm{~Hz}, \mathrm{O}-\mathrm{CH}_{2}\right), 6.96$ and 7.27 $\left(\mathrm{AA}^{\prime}\right.$ and $\mathrm{BB}^{\prime}, 2 \times 2 \mathrm{H}, J=9.0 \mathrm{~Hz}, \mathrm{CH}$ phenyl), 7.17-7.19 (m, 2H, N-CH-CH-N), 7.75 (broad s, $1 \mathrm{H}, \mathrm{N}-\mathrm{CH}-\mathrm{N}) .{ }^{13} \mathrm{C}$ NMR $(75$ $\left.\mathrm{MHz}, \mathrm{CDCl}_{3}\right): \delta=14.03\left(\mathrm{CH}_{3}\right.$ aliphatic), 22.61, 25.94, 29.13, 29.27, 29.30, 29.50, 29.52, 29.57, 29.59, $31.84\left(\mathrm{CH}_{2}\right.$ aliphatic), $68.40\left(\mathrm{O}-\mathrm{CH}_{2}\right), 115.39$ ( $\mathrm{CH}$ phenyl), $118.67(\mathrm{CH}$ imidazolium), 123.09 ( $\mathrm{CH}$ phenyl), 129.97 ( $\mathrm{CH}$ imidazolium), 130.47 (N-C phenyl), 135.79 (CH imidazolium), 158.48 (C-O$\mathrm{CH}_{2}$ phenyl). $v_{\max } / \mathrm{cm}^{-1} 3118$ (C-H aromatic), 2921 and 2851 (C-H aliphatic), 1520 ( $\mathrm{C}=\mathrm{C}$ aromatic), 1243 (C-O aromatic). $\mathrm{UV} / \mathrm{Vis}\left(\mathrm{CH}_{2} \mathrm{Cl}_{2}\right): \lambda_{\max }\left(\varepsilon, \mathrm{L} \cdot \mathrm{mol}^{-1} \cdot \mathrm{cm}^{-1}\right)=241 \mathrm{~nm}(15000)$. Elemental analysis for $\mathrm{C}_{21} \mathrm{H}_{32} \mathrm{~N}_{2} \mathrm{O}$, Cacld: C, 76.78; H, 9.82; N, 8.53\%. Found: C, 76.96; H, 10.58; N, 8.57\%.

\section{1-[4-(Dodecyloxy)phenyl]-3-methyl-1H- imidazol-3-ium iodide (1a)}

A mixture of A (1.069 g, $3.25 \mathrm{mmol})$ and iodomethane $(2 \mathrm{~mL}$, $31.80 \mathrm{mmol}$ ) was stirred in a sealed tube for $54 \mathrm{~h}$ and was heated to $40{ }^{\circ} \mathrm{C}$ for 10 minutes. Diethyl ether was added and the reaction mixture was filtered and the solid was washed with diethyl ether. Crystallization with dichloromethane and diethyl ether gave de 1a (1.318 g, 89\%).

${ }^{1} \mathrm{H} \mathrm{NMR}\left(300 \mathrm{MHz}, \mathrm{CDCl}_{3}\right): \delta=0.89\left(\mathrm{t}, 3 \mathrm{H}, J=6.9 \mathrm{~Hz}, \mathrm{CH}_{3}\right.$ aliphatic chain), 1.28 (broad s, $16 \mathrm{H}, \mathrm{CH}_{2}$ aliphatic chain), 1.41-1.48 (m, 2H, O- $\left.\mathrm{CH}_{2}-\mathrm{CH}_{2}-\mathrm{CH}_{2}\right), 1.76-1.85(\mathrm{~m}, 2 \mathrm{H}$, $\left.\mathrm{O}-\mathrm{CH}_{2}-\mathrm{CH}_{2}\right), 3.99$ (t, $\left.2 \mathrm{H}, J=6.6 \mathrm{~Hz}, \mathrm{O}-\mathrm{CH}_{2}\right), 4.27(\mathrm{~s}, 3 \mathrm{H}$, $\left.\mathrm{N}-\mathrm{CH}_{3}\right), 7.04$ and $7.66\left(\mathrm{AA}^{\prime}\right.$ and $\mathrm{BB}^{\prime}, 2 \times 2 \mathrm{H}, J=9.1 \mathrm{~Hz}, \mathrm{CH}$ phenyl), 7.46-7.48 (m, 2H, N-CH-CH-N), 10.45 (broad s, $1 \mathrm{H}$, $\mathrm{N}-\mathrm{CH}-\mathrm{N}) .{ }^{13} \mathrm{C} \mathrm{NMR}\left(75 \mathrm{MHz}, \mathrm{CDCl}_{3}\right): \delta=14.01\left(\mathrm{CH}_{3}\right.$ aliphatic), 22.58, 25.89, 29.00, 29.25, 29.29, 29.48, 29.51, 29.54, 29.57, $31.82\left(\mathrm{CH}_{2}\right.$ aliphatic), $37.57\left(\mathrm{~N}-\mathrm{CH}_{3}\right), 68.65$ $\left(\mathrm{O}-\mathrm{CH}_{2}\right), 115.99(\mathrm{CH}$ phenyl), $121.03(\mathrm{CH}$ imidazolium $)$, 123.65 (CH phenyl), 124.42 (CH imidazolium), 127.05 (N-C phenyl), 135.49 (CH imidazolium), 160.47 (C-O- $\mathrm{CH}_{2}$ phenyl). $v_{\max } / \mathrm{cm}^{-1} 3131$ (C-H aromatic), 2921 and 2851 (C-H 
aliphatic), $1514(\mathrm{C}=\mathrm{C}$ aromatic), 1251 (C-O aromatic). UV-vis $\left(\mathrm{CH}_{2} \mathrm{Cl}_{2}\right): \lambda_{\max }\left(\varepsilon, \mathrm{L} \cdot \mathrm{mol}^{-1} \cdot \mathrm{cm}^{-1}\right)=240 \mathrm{~nm}$ (24000). Elemental analysis for $\mathrm{C}_{22} \mathrm{H}_{35} \mathrm{IN}_{2} \mathrm{O} \cdot 1 / 4 \mathrm{H}_{2} \mathrm{O}$, Calcd: $\mathrm{C}, 55.64 ; \mathrm{H}, 7.53 ; \mathrm{N}$, 5.90\%. Found: C, 55.78; H, 7.48; N, 5.34\%.

\section{General procedure for metathesis in water-anion exchange}

A mixture of 1a dissolved in dichloromethane $(4 \mathrm{~mL})$ and a mixture of the corresponding salts dissolved in water $(3 \mathrm{~mL})$ were stirred together for $140 \mathrm{~h}$. The organic layer was separated off, washed with water and dried over calcium chloride. Crystallization with dichloromethane and diethyl ether gave the corresponding imidazolium salt.

\section{1-[4-(Dodecyloxy)phenyl]-3-methyl-1 H- imidazol-3-ium tetrafluoroborate (1b)}

Following the general procedure using $1 \mathrm{a}(0.797 \mathrm{~g}, 1.69 \mathrm{mmol})$ and sodium tetrafluoroborate $(0.511 \mathrm{~g}, 4.56 \mathrm{mmol})$ provided $\mathbf{1 b}$ with a yield of $72 \%(0.525 \mathrm{~g}, 1.22 \mathrm{mmol})$.

${ }^{1} \mathrm{H}$ NMR (300 MHz, $\left.\mathrm{CDCl}_{3}\right): \delta=0.86\left(\mathrm{t}, 3 \mathrm{H}, J=6.3 \mathrm{~Hz}, \mathrm{CH}_{3}\right.$ aliphatic chain), 1.28 (broad s, $16 \mathrm{H}, \mathrm{CH}_{2}$ aliphatic chain), 1.41-1.46 (m, 2H, O-CH $\left.-\mathrm{CH}_{2}-\mathrm{CH}_{2}\right), 1.75-1.84(\mathrm{~m}, 2 \mathrm{H}$, $\mathrm{O}-\mathrm{CH}_{2}-\mathrm{CH}_{2}$ ), 3.98 (t, $\left.2 \mathrm{H}, J=6.3 \mathrm{~Hz}, \mathrm{O}-\mathrm{CH}_{2}\right), 4.11(\mathrm{~s}, 3 \mathrm{H}$, $\left.\mathrm{N}-\mathrm{CH}_{3}\right), 7.02$ and $7.53\left(\mathrm{AA}^{\prime}\right.$ and $\mathrm{BB}^{\prime}, 2 \times 2 \mathrm{H}, J=9.0 \mathrm{~Hz}, \mathrm{CH}$ phenyl), 7.48 (broad s, 2H, N-CH-CH-N), 9.37 (broad s, $1 \mathrm{H}$, $\mathrm{N}-\mathrm{CH}-\mathrm{N}) \cdot{ }^{13} \mathrm{C}$ NMR $\left(75 \mathrm{MHz}, \mathrm{CDCl}_{3}\right): \delta=14.07\left(\mathrm{CH}_{3}\right.$ aliphatic), 22.65, 25.95, 29.08, 29.32, 29.37, 29.55, 29.59, 29.61, 29.64, $31.89\left(\mathrm{CH}_{2}\right.$ aliphatic), $36.81\left(\mathrm{~N}-\mathrm{CH}_{3}\right), 68.65$ $\left(\mathrm{O}-\mathrm{CH}_{2}\right), 115.96$ ( $\mathrm{CH}$ phenyl), 121.34 ( $\mathrm{CH}$ imidazolium), 123.59 ( $C H$ phenyl), 124.50 ( $C H$ imidazolium), 127.24 (N-C phenyl), 134.97 ( $\mathrm{CH}$ imidazolium), 160.47 ( $\mathrm{C}-\mathrm{O}-\mathrm{CH}_{2}$ phenyl). $v_{\max } / \mathrm{cm}^{-1} 2917$ and 2849 (C-H aliphatic), $1514(\mathrm{C}=\mathrm{C}$ aromatic), 1249 (C-O aromatic), $1024\left(\mathrm{BF}_{4}{ }^{-}\right)$. UV-vis $\left(\mathrm{CH}_{2} \mathrm{Cl}_{2}\right): \lambda_{\max }\left(\varepsilon, \mathrm{L} \cdot \mathrm{mol}^{-1} \cdot \mathrm{cm}^{-1}\right)=255 \mathrm{~nm}(10500)$. Elemental analysis for $\mathrm{C}_{22} \mathrm{H}_{35} \mathrm{BF}_{4} \mathrm{~N}_{2} \mathrm{O} \cdot 3 / 4 \mathrm{H}_{2} \mathrm{O}$, Calcd: C 59.53, H 8.29, N $6.31 \%$. Found: C 59.74, H 8.02, N 6.20\%.

\section{1-[4-(Dodecyloxy)phenyl]-3-methyl-1H- imidazol-3-ium hexafluorophosphate (1c)}

Following the general procedure using $1 \mathrm{a}(0.695 \mathrm{~g}, 1.48 \mathrm{mmol})$ and potassium hexafluoroborate $(0.518 \mathrm{~g}, 2.18 \mathrm{mmol})$ provided 1c with a yield of $84 \%(0.607 \mathrm{~g}, 1.24 \mathrm{mmol})$.

${ }^{1} \mathrm{H}$ NMR (300 MHz, $\left.\mathrm{CDCl}_{3}\right): \delta=0.89\left(\mathrm{t}, 3 \mathrm{H}, J=6.8 \mathrm{~Hz}, \mathrm{CH}_{3}\right.$ aliphatic chain), 1.28 (broad s, $16 \mathrm{H}, \mathrm{CH}_{2}$ aliphatic chain), 1.41-1.46 (m, 2H, O- $\left.\mathrm{CH}_{2}-\mathrm{CH}_{2}-\mathrm{CH}_{2}\right), 1.76-1.85(\mathrm{~m}, 2 \mathrm{H}$, $\mathrm{O}-\mathrm{CH}_{2}-\mathrm{CH}_{2}$ ), 3.98 (t, $\left.2 \mathrm{H}, J=6.6 \mathrm{~Hz}, \mathrm{O}-\mathrm{CH}_{2}\right), 4.07$ (s, 3H, $\left.\mathrm{N}-\mathrm{CH}_{3}\right), 7.02$ and $7.48\left(\mathrm{AA}^{\prime}\right.$ and $\mathrm{BB}^{\prime}, 2 \times 2 \mathrm{H}, \mathrm{J}=8.8 \mathrm{~Hz}, \mathrm{CH}$ phenyl), 7.45 (broad s, 2H, N-CH-CH-N), 9.10 (broad s, $1 \mathrm{H}$, $\mathrm{N}-\mathrm{CH}-\mathrm{N}) .{ }^{13} \mathrm{C} \mathrm{NMR}\left(75 \mathrm{MHz}, \mathrm{CDCl}_{3}\right): \delta=14.06\left(\mathrm{CH}_{3}\right.$ aliphatic), 22.65, 25.95, 29.08, 29.32, 29.37, 29.55, 29.59, 29.61, 29.64, $31.89\left(\mathrm{CH}_{2}\right.$ aliphatic), $36.81\left(\mathrm{~N}-\mathrm{CH}_{3}\right), 68.65$ $\left(\mathrm{O}-\mathrm{CH}_{2}\right), 115.91$ ( $\mathrm{CH}$ phenyl), $121.60(\mathrm{CH}$ imidazolium), 123.70 (CH phenyl), 124.33 (CH imidazolium), 127.21 (N-C phenyl), 134.42 ( $\mathrm{CH}$ imidazolium), 160.51 ( $\mathrm{C}-\mathrm{O}-\mathrm{CH}_{2}$ phenyl). $v_{\max } / \mathrm{cm}^{-1} 2921$ and 2850 (C-H aliphatic), $1516(\mathrm{C}=\mathrm{C}$ aromatic), 1255 (C-O aromatic), $826 \mathrm{~cm}^{-1}\left(\mathrm{PF}_{6}{ }^{-}\right)$. UV-vis $\left(\mathrm{CH}_{2} \mathrm{Cl}_{2}\right): \lambda_{\max }\left(\varepsilon, \mathrm{L} \cdot \mathrm{mol}^{-1} \cdot \mathrm{cm}^{-1}\right)=249 \mathrm{~nm}(11700)$. Elemental analysis for $\mathrm{C}_{22} \mathrm{H}_{35} \mathrm{~F}_{6} \mathrm{~N}_{2} \mathrm{OP} \cdot 1 / 7 \mathrm{H}_{2} \mathrm{O}$, Calcd: C 53.81, H 7.24, N 5.70\%. Found: C 53.77, H 7.31, N 5.51\%.

\section{1-[4-(Dodecyloxy)phenyl]-3-methyl-1H-} imidazol-3-ium trifluoromethanesulfonate (1d) Following the general procedure using $1 \mathbf{a}(0.730 \mathrm{~g}, 1.55 \mathrm{mmol})$ and sodium trifluoromethanesulfonate $(0.616 \mathrm{~g}, 3.51 \mathrm{mmol})$ provided 1d with a yield of $46 \%(0.349 \mathrm{~g}, 0.71 \mathrm{mmol})$.

${ }^{1} \mathrm{H}$ NMR $\left(300 \mathrm{MHz}, \mathrm{CDCl}_{3}\right): \delta=0.89\left(\mathrm{t}, 3 \mathrm{H}, J=6.8 \mathrm{~Hz}, \mathrm{CH}_{3}\right.$ aliphatic chain), 1.28 (broad s, $16 \mathrm{H}, \mathrm{CH}_{2}$ aliphatic chain), 1.41-1.46 (m, 2H, O- $\left.\mathrm{CH}_{2}-\mathrm{CH}_{2}-\mathrm{CH}_{2}\right), 1.76-1.83(\mathrm{~m}, 2 \mathrm{H}$, $\mathrm{O}-\mathrm{CH}_{2}-\mathrm{CH}_{2}$ ), 3.99 (t, $\left.2 \mathrm{H}, \mathrm{J}=6.6 \mathrm{~Hz}, \mathrm{O}-\mathrm{CH}_{2}\right), 4.10(\mathrm{~s}, 3 \mathrm{H}$, $\left.\mathrm{N}-\mathrm{CH}_{3}\right), 7.02$ and $7.51\left(\mathrm{AA}^{\prime}\right.$ and $\mathrm{BB}^{\prime}, 2 \times 2 \mathrm{H}, J=8.8 \mathrm{~Hz}, \mathrm{CH}$ phenyl), 7.49 (broad s, 2H, N-CH-CH-N), 9.41 (broad s, 1H, $\mathrm{N}-\mathrm{CH}-\mathrm{N}) .{ }^{13} \mathrm{C} \mathrm{NMR}\left(75 \mathrm{MHz}, \mathrm{CDCl}_{3}\right): \delta=13.96\left(\mathrm{CH}_{3}\right.$ aliphatic), 22.54, 25.85, 28.97, 29.21, 29.26, 29.44, 29.48, 29.51, 29.53, $31.78\left(\mathrm{CH}_{2}\right.$ aliphatique), $36.52\left(\mathrm{~N}-\mathrm{CH}_{3}\right), 68.54$ $\left(\mathrm{O}-\mathrm{CH}_{2}\right), 115.84(\mathrm{CH}$ phenyl), 120.49 (q, $J=318.18 \mathrm{~Hz}$, $\mathrm{CF}_{3} \mathrm{SO}_{3}{ }^{-}$), 121.36 ( $\mathrm{CH}$ imidazolium), 123.33 ( $\mathrm{CH}$ phenyl), 124.44 ( $\mathrm{CH}$ imidazolium), 127.15 (N-C phenyl), $134.95(\mathrm{CH}$ imidazolium), 160.36 (C-O-CH 2 phenyl). $v_{\max } / \mathrm{cm}^{-1} 3119(\mathrm{C}-\mathrm{H}$ aromatic), 2915 and 2849 (C-H aliphatic), $1520(\mathrm{C}=\mathrm{C}$ aromatic), 1269 and $1028\left(\mathrm{CF}_{3} \mathrm{SO}_{3}{ }^{-}\right)$. UV-vis $\left(\mathrm{CH}_{2} \mathrm{Cl}_{2}\right): \lambda_{\max }$ $\left(\varepsilon, \mathrm{L} \cdot \mathrm{mol}^{-1} \cdot \mathrm{cm}^{-1}\right)=256 \mathrm{~nm}(10100)$. Elemental analysis for $\mathrm{C}_{22} \mathrm{H}_{35} \mathrm{~F}_{3} \mathrm{~N}_{2} \mathrm{O}_{4} \mathrm{~S}$, Cacld: C 56.08, H 7.16, N 6.59\%. Found: C 55.84, H 6.86, N 5.40\%.

\section{1-[4-(Dodecyloxy)phenyl]-3-methyl-1H- imidazol-3-ium bis(trifluoromethane) sulfon- amide (1e)}

$1 \mathrm{a}(0.101 \mathrm{~g}, 0.21 \mathrm{mmol})$ and lithium bis(trifluoromethane)sulfonamide (0.145 g, $0.51 \mathrm{mmol})$ were dissolved in water (3 $\mathrm{mL})$ and stirred for $140 \mathrm{~h}$. The precipitate was filtred and washed. Crystallization (chloroform/cyclohexane) provided $1 \mathbf{e}$ with a yield of $90 \%(0.121 \mathrm{~g}, 0.19 \mathrm{mmol})$.

${ }^{1} \mathrm{H}$ NMR (300 MHz, $\left.\mathrm{CDCl}_{3}\right): \delta=0.89\left(\mathrm{t}, 3 \mathrm{H}, J=6.8 \mathrm{~Hz}, \mathrm{CH}_{3}\right.$ aliphatic chain), 1.28 (broad s, $16 \mathrm{H}, \mathrm{CH}_{2}$ aliphatic chain), 1.42-1.52 (m, 2H, O-CH $\left.-\mathrm{CH}_{2}-\mathrm{CH}_{2}\right), 1.77-1.86(\mathrm{~m}, 2 \mathrm{H}$, $\mathrm{O}-\mathrm{CH}_{2}-\mathrm{CH}_{2}$ ), 4.01 (t, $\left.2 \mathrm{H}, J=6.6 \mathrm{~Hz}, \mathrm{O}-\mathrm{CH}_{2}\right), 4.07$ (s, 3H, $\left.\mathrm{N}-\mathrm{CH}_{3}\right), 7.05$ and $7.46\left(\mathrm{AA}^{\prime}\right.$ and $\mathrm{BB}^{\prime}, 2 \times 2 \mathrm{H}, J=8.8 \mathrm{~Hz}, \mathrm{CH}$ phenyl), 7.43-7.49 (m, 2H, N-CH-CH-N), 8.98 (broad s, 1H, 
$\mathrm{N}-\mathrm{CH}$-N). ${ }^{13} \mathrm{C}$ NMR $\left(75 \mathrm{MHz}, \mathrm{CDCl}_{3}\right): \delta=14.06\left(\mathrm{CH}_{3}\right.$ aliphatic), 22.65, 25.94, 29.05, 29.31, 29.34, 29.53, 29.57, 29.60, 29.63, $31.89\left(\mathrm{CH}_{2}\right.$ aliphatic $), 36.69\left(\mathrm{~N}-\mathrm{CH}_{3}\right), 68.70$ $\left(\mathrm{O}-\mathrm{CH}_{2}\right), 116.04$ ( $\mathrm{CH}$ phenyl), 119.77 (q, $J=319.29 \mathrm{~Hz}$, $\mathrm{CF}_{3} \mathrm{SO}_{3}{ }^{-}$), 121.89 ( $\mathrm{CH}$ imidazolium), 123.77 ( $\mathrm{CH}$ phenyl), 124.31 ( $\mathrm{CH}$ imidazolium), 126.99 (N-C phenyl), 134.67 ( $\mathrm{CH}$ imidazolium), 160.78 (C-O-CH 2 phenyl). $v_{\max } / \mathrm{cm}^{-1} 2918$ and 2850 (C-H aliphatic), $1517\left(\mathrm{C}=\mathrm{C}\right.$ aromatic), $1358 \mathrm{~cm}^{-1}$ and $1183\left(\left(\mathrm{CF}_{3} \mathrm{SO}_{2}\right)_{2} \mathrm{~N}^{-}\right)$. UV-vis $\left(\mathrm{CH}_{2} \mathrm{Cl}_{2}\right): \lambda_{\max }(\varepsilon$, $\left.\mathrm{L} \cdot \mathrm{mol}^{-1} \cdot \mathrm{cm}^{-1}\right)=255 \mathrm{~nm}(11100)$. Elemental analysis for $\mathrm{C}_{24} \mathrm{H}_{35} \mathrm{~F}_{6} \mathrm{~N}_{3} \mathrm{O}_{5} \mathrm{~S}_{2 \cdot 1 / 2} \mathrm{H}_{2} \mathrm{O}$, Cacld: C 45.56, H 5.74, N 6.64\%. Found: C 45.52, H 5.66, N 6.58\%.

\section{Acknowledgements}

We are especially grateful to Dr. J. Harrowfield for the critical evaluation of the manuscript. This work was supported by the Institut for Physics and Chemistry of Materials Strasbourg and University of Strasbourg.

\section{References}

1. Wasserscheid, P.; Welton, T. Ionic Liquid in Synthesis; Wiley-VCH: Weinheim, Germany, 2003.

2. Rogers, R. B.; Seddon, K. R., Eds. Ionic Liquids IIIA: Fundamentals, Progress, Challenges and Opportunities, American Chemical Society, Symp. Ser.: Washington DC, 2005. doi:10.1021/bk-2005-0901

3. Rogers, R. B.; Seddon, K. R., Eds. Ionic Liquids IIIB: Fundamentals, Progress, Challenges and Opportunities, American Chemical Society, Symp. Ser.: Washington DC, 2005. doi:10.1021/bk-2005-0902

4. Dupont, J.; de Souza, R. F.; Suarez, P. A. Chem. Rev. 2002, 102, 3667-3692. doi:10.1021/cr010338r

5. Endres, F.; Abbott, A. P.; MacFarlane, D. R. Electrodeposition from Ionic liquids; Wiley-VCH: Weinheim, 2008. doi:10.1002/9783527622917

6. Handbook of Liquid Crystals, Vols. 1, 2a, 2b and 3. Demus, D.; Goodby, J. W.; Gray, G. W.; Spiess, H.-W.; Vill, V., Eds.; Wiley-VCH: Weinheim, 1998.

7. Guillon, D. Struct. Bond. 1999, 95, 41-82. doi:10.1007/3-540-68118-3_2

8. Goodby, J. W.; Saez, I. M.; Cowling, S. J.; Görtz, V.; Draper, M.; Hall, A. W.; Sia, S.; Cosquer, G.; Lee, S.-E.; Raynes, E. P. Angew. Chem., Int. Ed. 2008, 47, 2754-2787. doi:10.1002/anie.200701111

9. Dobbs, W.; Heinrich, B.; Bourgogne, C.; Donnio, B.; Terazzi, E.; Bonnet, M.-E.; Stock, F.; Erbacher, P.; Bolcato-Bellemin, A.-L.; Douce, L. J. Am. Chem. Soc. 2009, 131, 13338-13346. doi:10.1021/ja903028f

10. Ohno, H. Electrochemical Aspect of Ionic Liquids; John Wiley and Sons, 2005. doi:10.1002/0471762512

11. Binnemans, K. Chem. Rev. 2005, 105, 4148-4204. doi:10.1021/cr0400919

12. Bowlas, C. J.; Bruce, D. W.; Seddon, K. R. Chem. Commun. 1996, 1625-1626. doi:10.1039/cc9960001625

13. Yoshio, M.; Mukai, T.; Ohno, H.; Kato, T. J. Am. Chem. Soc. 2004, 126, 994-995. doi:10.1021/ja0382516

14. Taubert, A. Angew. Chem., Int. Ed. 2004, 43, 5380-5382. doi:10.1002/anie.200460846
15. Suisse, J.-M.; Bellemin-Laponnaz, S.; Douce, L.; Maisse-François, A.; Welter, R. Tetrahedron Lett. 2005, 46, 4303-4305. doi:10.1016/j.tetlet.2005.04.114

16. Dobbs, W.; Suisse, J.-M.; Douce, L.; Welter, R. Angew. Chem., Int. Ed. 2006, 45, 4179-4182. doi:10.1002/anie.200600929

17. Dobbs, W.; Douce, L.; Allouche, L.; Louati, A.; Malbosc, F.; Welter, R. New J. Chem. 2006, 30, 528-532. doi:10.1039/b600279j

18. Suisse, J.-M.; Douce, L.; Bellemin-Laponnaz, S.; Maisse-François, A.; Welter, R.; Miyake, Y.; Shimizu, Y. Eur. J. Inorg. Chem. 2007, 3899-3905. doi:10.1002/ejic.200700251

19. Yazaki, S.; Kamikawa, Y.; Yoshio, M.; Hamasaki, A.; Mukai, T.; Ohno, H.; Kato, T. Chem. Lett. 2008, 37, 538-539. doi:10.1246/cl.2008.538

20. Yoshio, M.; Ichikawa, T.; Shimura, H.; Kagata, T.; Hamasaki, A.; Mukai, T.; Ohno, H.; Kato, T. Bull. Chem. Soc. Jpn. 2007, 80, 1836-1841. doi:10.1246/bcsj.80.1836

21. Fanta, P. E. Synthesis 1974, 9-21. doi:10.1055/s-1974-23219

22. Kouwer, P. H. J.; Swager, T. M. J. Am. Chem. Soc. 2007, 129, 14042-14052. doi:10.1021/ja075651a

23. Kantam, M. L.; Rao, B. P. C.; Choudary, B. M.; Reddy, R. S. Synlett 2006, 14, 2195-2198. doi:10.1055/s-2006-949615

24. Spek, A. L. J. Appl. Crystallogr. 2003, 36, 7-13. doi:10.1107/S0021889802022112

25. Cruz, C.; Heinrich, B.; Ribeiro, A. C.; Bruce, D. W.; Guillon, D. Liq. Cryst. 2000, 27, 1625-1631. doi:10.1080/026782900750037185

26. Dobbs, W.; Heinrich, B.; Douce, L. Beilstein J. Org. Chem. 2009, 5 , No. 62. doi:10.3762/bjoc.5.62

\section{License and Terms}

This is an Open Access article under the terms of the Creative Commons Attribution License (http://creativecommons.org/licenses/by/2.0), which permits unrestricted use, distribution, and reproduction in any medium, provided the original work is properly cited.

The license is subject to the Beilstein Journal of Organic Chemistry terms and conditions:

(http://www.beilstein-journals.org/bjoc)

The definitive version of this article is the electronic one which can be found at: doi:10.3762/bjoc.5.51 